Bayero Journal of Pure and Applied Sciences, 11(1): 73 - 78

ISSN 2006 - 6996

\title{
ASSESSMENT OF HEAVY METALS CONTAMINATION IN THE SEDIMENT OF YARDANTSI RESERVOIR, GUSAU NIGERIA
}

\author{
Jabbi, A.M.*1, Rabiu, A.T. ${ }^{1}$, Sani, Z.R. ${ }^{2}$, Balarabe, M.L. ${ }^{3}$ and Adamu, A.K. ${ }^{4}$ \\ ${ }^{1}$ Department of Biological Sciences, Faculty of Science, Nigeria Police Academy, Wudil \\ ${ }^{2}$ Department of Biological Sciences, Faculty of Science, Federal University, Gusau, Nigeria \\ ${ }^{3}$ Department of Biology, Faculty of Life Sciences, Ahmadu Bello University, Zaria, Nigeria \\ ${ }^{4}$ Department of Botany, Faculty of Life Sciences, Ahmadu Bello University, Zaria, Nigeria \\ *Correspondence author: jabbiam99@gmail.com, +2348030985166
}

\begin{abstract}
The magnitude and ecological relevance of metals pollution in the sediment of Yardantsi Reservoir, Gusau Nigeria, which serve as main source of water for irrigation and municipalities was assessed by applying sets of complementary sediment quality assessment methods; The contamination factor $\left(C_{f}\right)$; and comparisons with concentration based sediment quality guidelines (CBSQGs) of target heavy metals. The sediment metals concentrations in the reservoir were investigated from May, 2015 to April, 2017. Sediment samples were collected from five sampling stations and analysed using Shimadzu AA6800 Atomic Absorbtion Spectrophotometry. The results showed that $C d$ has a mean concentration of $(1.81 \mathrm{cmol} / \mathrm{kg})$, $\mathrm{Cu}(3.40 \mathrm{cmol} / \mathrm{kg}), \mathrm{Cr}(0.99 \mathrm{cmol} / \mathrm{kg}), \mathrm{Fe}(46.71 \mathrm{cmol} / \mathrm{kg}), \mathrm{Ni}(0.50 \mathrm{cmol} / \mathrm{kg}), \mathrm{Pb}(0.14 \mathrm{cmol} / \mathrm{kg})$, and $\mathrm{Zn}(13.87 \mathrm{cmol} / \mathrm{kg})$. Contamination factor $\left(C_{f}\right)$ and CBSQGs suggested that cadmium concentration was slightly higher as $C_{f}>6$ and exceeded threshold effects concentrations (TECs). This may cause adverse biological effects and the reservoir was in potential risk with regards to Cd concentration, while the rest of the metals were found to be lower than the proposed TECs and has $C_{f}<1$ indicating that there are no harmful effects from these metals. It is suggested that the reservoir input should be monitored and the sediment sources be mitigated.
\end{abstract}

Keywords: Assessment, contamination, heavy metals, reservoir, sediment

\section{INTRODUCTION}

In the past few decades, heavy metals accumulation in the environment has been attracting increasing attention from researchers and policy makers because of their toxicity, persistence in the environment and subsequent accumulation in aquatic habitats (Fifi et al., 2013; Guan et al., 2014). Sediments play a major role in determining the pollution patterns of aquatic systems. They act as both carriers and sinks for contaminants, reflecting the history of pollution, and providing a record of catchment inputs into aquatic ecosystems (Cevik et al., 2009). On the basis of earlier researches (Zhang et al., 2009), a comprehensive and reliable scheme of the preliminary risk assessment of metal contamination in surface sediments should contain: comparisons of concentrations with the values of sediment quality guidelines of metals; and evaluation of combined pollution. The sediment quality guidelines (SQGs) have been used to identify "contaminants of concern" in aquatic ecosystems and to rank "areas of concern" on a regional or national basis, and have also been used in numerous other applications, including the design of monitoring programs, interpreting historical Due to chemical and geological conditions, heavy metals in sediments can exist in different data, conducting remedial investigations and ecological risk assessments and so on. Many different SQGs have been developed (Long et al., 1998; Macdonald et al., 2000). SQGs are very important for protection of benthic organisms in freshwater ecosystems and can be used to assess sediment ecosystem health (Cevik et al., 2009). Anthropogenic activities such as agriculture, industrial and domestic discharges have contributed to the deterioration of the environment (Ansari et al., 2014; Van Dover et al., 2014). Pollutants from these activities are released either directly into the aquatic ecosystem in the form of wastewater discharges, oil spillages, agricultural run-offs (Hassan et al., 2014; Bako et al., 2014), or indirectly through deposition from soil or air within the catchment of such water bodies (Bako et al., 2014).

In recent years there have been increasing concern about the rate at which inland waters are polluted through human activities, agriculture waste, manure, fertilizers and pesticides, which find their way through runoffs into streams and lakes there by enriching the water bodies, leading to eutrophication (Adakole et al., 2003). 
forms: soluble, exchangeable, bound to organic matter, occluded in $\mathrm{Mn}$ and/or Fe oxides, as a component of carbonates, phosphates, sulphurs, or other secondary minerals, or bound to silicates residues (Devesa-Rey et al., 2010). Thus, the carrier operationally defined phases analysis of heavy metals might provide much useful information regarding the chemical nature or potential mobility and bioavailability of a particular element, which consequently can offer a more realistic estimate of actual environmental impact (Yang et al., 2009). The concentration of heavy metals in sediments can be a secondary source of water pollution, once environmental condition is changed (Cheung et al., 2003). Therefore, an assessment of heavy metal contamination in sediments is an indispensable tool to assess the risk of an aquatic environment. The data provided in this study is considered to be very important for reservoir remediation, especially since the Reservoir serve as one of the main sources of drinking water for Gusau populace. This research was aimed to investigate the environmental risk associated with the metal concentrations of sediments using available SQGs; in order to evaluate their relative mobility and bioavailability.

\section{MATERIALS AND METHODS}

\section{Study Area}

The reservoir is located in Gusau Local Government Area of Zamfara State, (Figure 1), North-western Nigeria, located between latitude $12^{\circ} 10^{\prime} 12.86^{\prime \prime}$ - $12^{\circ} 17^{\prime} 02.40^{\prime \prime} \mathrm{N}$ and longitude $6^{\circ} 39 ' 50.83^{\prime \prime}$ - $6^{\circ} 66^{\prime} 41.20^{\prime \prime} \quad E$ and occupies an area of $3,364 \mathrm{~km}^{2}(1,298.8 \mathrm{sqmi})$. Gusau Local Government had a population of 383,162 people (NPC, 2006). The hottest months in the area are March and April that is just before the onset of the first rains. The onset of the rains tends to bring a cooling effect with temperatures dropping below 36 ${ }^{\circ} \mathrm{C}$. The peak of the rainy season is from July to September except towards the end of October/November when the tropical continental air masses from the Sahara predominate which leads to lower temperatures of around $17^{\circ} \mathrm{C}-20^{\circ} \mathrm{C}$. The mean annual rainfall in the area is $990 \mathrm{~mm}$. The type of vegetation in this area is the Sudan savannah (Mamman et al., 2000).

\section{Collection and Processing of Sediment \\ Samples}

Sediment samples were collected from three different spot of each station using a plastic container. Samples were then homogenised together to form a homogenous mixture and then sealed in a clean labelled polythene bags, and then transported to Laboratory in a cooled box. The samples were air dried and ground into powder using pestle and a mortar and later sieved through $1.7 \mu \mathrm{m}$ mesh to remove the debris. Five sediment samples were collected for each sampling month, representing one sample per station, totalling to one hundred and twenty (120) number of sediment samples.

\section{Sediment Digestion and Analysis}

Using $100 \mathrm{ml}$ plastic bottle, without rubber stopper, $5 \mathrm{~g}$ of the sediment sample was added and later $50 \mathrm{ml}$ of $0.01 \mathrm{M} \mathrm{HCl}$, the mixture was homogenised with mechanical shaker for 30 minutes and heated to almost dryness on hot plate and then filtered through a Whatman No. 42 filter paper. The filtrate was used for the determination of the heavy metals of interest (viz; chromium, nickel, cadmium, zinc, iron, copper and lead) using Shimadzu AA6800 Atomic Absorbtion Spectrophotometry (AAS) as described by (Udo et al., 2009; APHA, 2005).

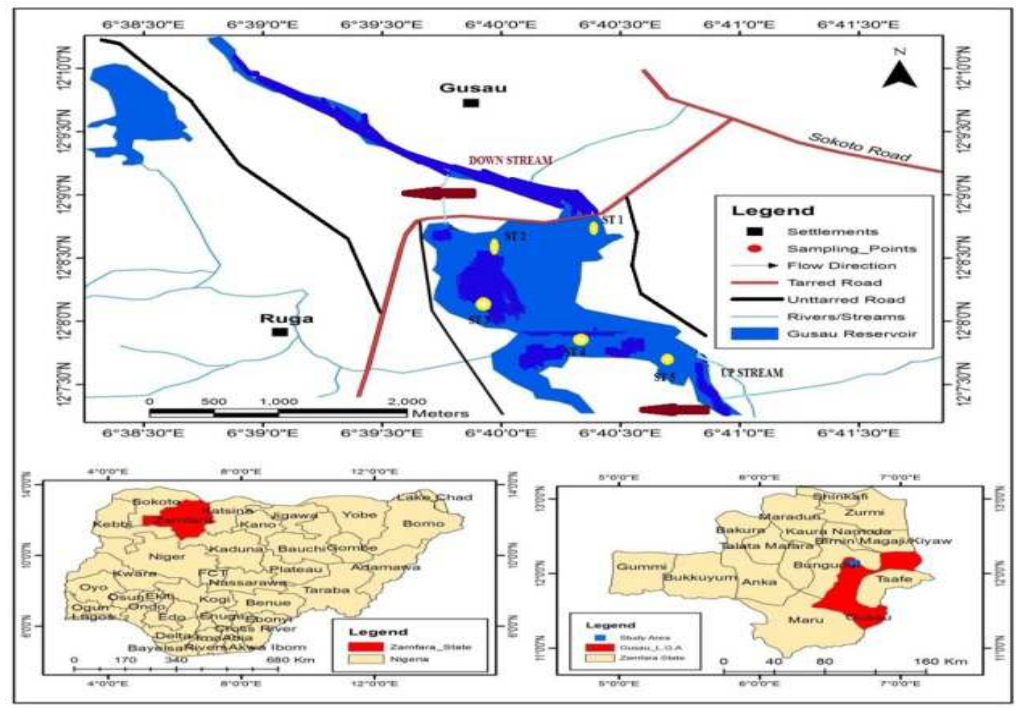

Figure 1: Study Area Map Showing Yardantsi Reservoir, Gusau 


\section{Assessment of Contamination Status}

The contamination status of the Reservoir sediment was assessed by determining the following;

Contamination Factor $\left(\mathrm{C}_{\mathrm{f}}\right)$

The degree to which sediment is contaminated is often express as contamination factors $\left(C_{f}\right)$ or enrichment ratio $\left(E_{R}\right)$, which was used to determine the sediment heavy metals contamination. Hakanson's classification for the contamination factor and level of contamination was used to determine the level/ status of contamination, which consists of seven grades ranging from low contamination to very high contamination (Table 2 ).

$$
C_{f}=\frac{C_{\text {metal }}}{C_{\text {background value }}}
$$

Where $C_{\text {metal }}$ is the measured metal concentration and $C_{\text {background }}$ represent the average background concentration of the metal in sediment. The geochemical background concentrations in shale of the metals under investigation $(\mathrm{Cd}=0.2 ; \mathrm{Cr}=63.8 ; \mathrm{Cu}=32 ; \mathrm{Ni}=$ 25.4; $\mathrm{Pb}=20$ and $\mathrm{Zn}=129$ ) earlier reported by Martin and Meybeck (1979) were used as background concentrations.

Table 1; Hakanson's Classification for the Contamination Factor and Level of Contamination (Hakanson,1980; Nasr et al., 2006)

\begin{tabular}{ll}
\hline Contamination factor $(\mathbf{C f})$ & Level of contamination \\
\hline $\mathrm{C}_{\mathrm{f}}<1$ & Low contamination \\
$1 \leq \mathrm{C}_{\mathrm{f}}<3$ & Moderate contamination \\
$3<\mathrm{C}_{\mathrm{f}}<6$ & Considerate (high) contamination \\
$\mathrm{C}_{\mathrm{f}}>6$ & Very high contamination \\
\hline
\end{tabular}

Numerical Sediment Quality Guidelines (SQGs) SQGs values for metals used in doing assessments of sediment quality in this studies include;

Consensus-Based Sediment Quality Guidelines for Freshwater Ecosystems (CBSQG 2000)

CBSQG defined the Threshold Effect Concentration (TEC) and a Probable Effect Concentration (PEC) for the sediment metals (Macdonald et al., 2000); if the metals in sediments are below the TEC, harmful effects are unlikely to be observed. If the metals are above the PEC, harmful effects are likely to be values. observed. Previous researchers (Saha and Hossain 2011), noted in his studies that most of the TEC provide an accurate basis for predicting the absence of sediment toxicity, and most of the PECs, provide an accurate basis for predicting sediment toxicity.

USEPA Guidelines for Sediments Quality

United State environmental protection agency guidelines for sediments metals were used to assess the level of metals contamination in the sediments by comparing the values obtained with guideline

Table 2; USEPA Guidelines for Sediments (mg/Kg dry weights) (Saha and Hossain 2011)

\begin{tabular}{lllll}
\hline Metal & Not polluted & Moderately polluted & Heavily polluted & Present study \\
\hline $\mathrm{Cd}$ & - & - & $>6$ & 1.81 \\
$\mathrm{Cr}$ & $<25$ & $25-75$ & $>75$ & 0.99 \\
$\mathrm{Cu}$ & $<25$ & $25-50$ & $>50$ & 3.40 \\
$\mathrm{Ni}$ & $<20$ & $20-25$ & $>50$ & 0.50 \\
$\mathrm{~Pb}$ & $<40$ & $40-60$ & $>60$ & 0.14 \\
$\mathrm{Zn}$ & $<90$ & $90-200$ & $>200$ & 13.87 \\
\hline
\end{tabular}

Data Analysis

IBM SPSS Statistics software version 22 was used for the; Two-way analysis of variance (ANOVA) to analyze the sediments metals results for significant difference $(p<0.05)$ between the means.

\section{RESULTS AND DISCUSSION}

The concentrations of heavy metals in sediment may be attributed to the nature of the catchment area, ground water loading and the components of the various types of fertilizers, pesticides, herbicides and atmospheric sources (burning of fuels). During rainy season metals which form the bulk of fertilizers find their way in to the river through surface runoff. Metals concentration also defend on certain physicochemical parameters acting on the water or sediment most especially $\mathrm{pH}$ and temperature. Decrease in $\mathrm{pH}$ favour the retention time of some metals in the free water (Abata et al., 2013). 


\section{Contamination Factor $\left(\mathbf{C}_{\mathrm{f}}\right)$}

Table 3 presented the mean concentrations of the reservoir sediment heavy metals, TEC, PEC and $C_{f}$. The $C_{f}$ values obtained shows that all the metals under consideration (chromium, copper, nickel, lead and zinc) with the exception of cadmium were found to have $C_{f}$ values less than one $\left(C_{f}<1\right)$ in all the sampling months and therefore are said to be low contaminated when compared with Hakanson's classification for the contamination factor and level of contamination (Table 1), while the cadmium $C_{f}$ value was found to be greater than $\operatorname{six}\left(C_{f}>6\right)$ and therefore is said to be very highly contaminated. The concentration of these metals in the sediments may be attributed to the fact that the reservoir receives surface runoff which introduces certain pollutants from catchment areas exposed to agricultural activities such as use of fertilizer and some form of pesticides and herbicides. This is in agreement with the findings of Abata et al., (2013) and Sabo et al., (2013) in their studies on Ala River in South-western -Nigeria and River Delimi Jos, Nigeria respectively. Fishel (2014) also reported that agricultural use of products containing copper is also common, especially in pesticides applied in vineyards and orchards.

\section{Consensus-Based Sediment Quality Guidelines for Freshwater Ecosystems}

The sediment concentrations of chromium, copper, nickel, lead and zinc in all the sampling months were found to be lower than the proposed threshold effects concentration (TEC), indicating that there are no harmful effects from these metals. On the other hand, the concentrations of cadmium exceeded TEC in all sampling months but less than probable effects concentrations (PEC); this indicated that the reservoir sediment was in potential risk. This is in agreement with the findings of (Balarabe, 1989; Sabo et al., 2013), in their studies on Ala River in South-western Nigeria and River Delimi Jos, Nigeria respectively.

\section{USEPA Guidelines for Sediments Quality}

The sediment metals concentrations were compared with the United State environmental protection agency guidelines for sediments metals (Table 2) to assess the level of metals contamination, this showed that all the metals has there concentrations lower than the contamination values in all sampling months, which indicated that there are no harmful effects from these metals to the reservoir sediment.

Table 3; Mean $( \pm \mathrm{SE})$ Monthly Variation of Different Sediment Heavy Metal $(\mathrm{cmol} / \mathrm{kg})$ for Yardantsi Reservoir, Gusau and SQGs Effect-Based Concentrations

\begin{tabular}{|c|c|c|c|c|c|c|c|}
\hline Months & $\mathrm{Cd}$ & $\mathrm{Cu}$ & $\mathrm{Cr}$ & $\mathrm{Fe}$ & $\mathrm{Ni}$ & $\mathrm{Pb}$ & $\mathrm{Zn}$ \\
\hline May & $\begin{array}{l}1.74 \pm \\
0.28^{\mathrm{c}, \mathrm{d}, \mathrm{e}, \mathrm{f}}\end{array}$ & $\begin{array}{l}4.91 \pm \\
0.45^{\mathrm{a}}\end{array}$ & $\begin{array}{l}0.80 \pm \\
0.06_{a, e, f}\end{array}$ & $\begin{array}{l}51.77 \pm \\
4.21^{\mathrm{a}, \mathrm{b}, \mathrm{c}}\end{array}$ & $\begin{array}{l}0.44 \pm \\
0.09_{a, b}\end{array}$ & $\begin{array}{l}0.07 \pm \\
0.01^{d}\end{array}$ & $\begin{array}{l}13.71 \pm \\
0.82^{a, b}\end{array}$ \\
\hline June & $\begin{array}{l}1.91 \pm \\
0.41^{\mathrm{b}, \mathrm{c}, \mathrm{d}, \mathrm{e}}\end{array}$ & $\begin{array}{l}4.73 \pm \\
0.57^{a}\end{array}$ & $\begin{array}{l}0.77_{ \pm} \\
0.07_{\mathrm{a}, \mathrm{e}, \mathrm{f}}\end{array}$ & $\begin{array}{l}42.15 \pm \\
8.67^{b, c}\end{array}$ & $\begin{array}{l}0.43 \pm \\
0.11_{a, b}\end{array}$ & $\begin{array}{l}0.16 \pm \\
0.03^{b, c}\end{array}$ & $\begin{array}{l}11.57 \pm \\
1.44^{\mathrm{a}, \mathrm{b}}\end{array}$ \\
\hline July & $\begin{array}{l}1.30 \pm \\
0.17^{\mathrm{e}, \mathrm{f}}\end{array}$ & $\begin{array}{l}3.82 \pm \\
0.30^{a, b, c}\end{array}$ & $\begin{array}{l}1.06 \pm \\
0.16_{a, e, f}\end{array}$ & $\begin{array}{l}40.38 \pm \\
7.59^{\mathrm{b}, \mathrm{c}}\end{array}$ & $\begin{array}{l}0.47 \pm \\
0.10_{a, b}\end{array}$ & $\begin{array}{l}0.18 \pm \\
0.02^{\mathrm{b}}\end{array}$ & $\begin{array}{l}22.52 \pm \\
12.97^{a}\end{array}$ \\
\hline August & $\begin{array}{l}1.09 \pm \\
0.12^{\mathrm{e}, \mathrm{f}}\end{array}$ & $\begin{array}{l}2.82 \pm \\
0.29^{\mathrm{c}, \mathrm{d}}\end{array}$ & $\begin{array}{l}0.54 \pm \\
0.09_{a, d}\end{array}$ & $\begin{array}{l}44.00 \pm \\
6.38^{\mathrm{b}, \mathrm{c}}\end{array}$ & $\begin{array}{l}0.54 \pm \\
0.09_{a, b}\end{array}$ & $\begin{array}{l}0.17 \pm \\
0.02^{\mathrm{b}}\end{array}$ & $\begin{array}{l}7.76 \pm \\
1.54^{\mathrm{b}}\end{array}$ \\
\hline September & $\begin{array}{l}1.43 \pm \\
0.19^{\mathrm{e}, \mathrm{f}}\end{array}$ & $\begin{array}{l}4.46 \pm \\
0.52^{a, b}\end{array}$ & $\begin{array}{l}2.23 \pm \\
0.92_{\mathrm{e}}\end{array}$ & $\begin{array}{l}36.46 \pm \\
6.77^{c}\end{array}$ & $\begin{array}{l}0.67 \pm \\
0.06_{b}\end{array}$ & $\begin{array}{l}0.09_{ \pm} \\
0.01^{d}\end{array}$ & $\begin{array}{l}12.19_{ \pm} \\
1.51^{\mathrm{a}, \mathrm{b}}\end{array}$ \\
\hline October & $\begin{array}{l}1.65_{ \pm}^{ \pm} \\
0.27^{\mathrm{d}, e, f}\end{array}$ & $\begin{array}{l}4.18 \pm \\
0.69^{a, b}\end{array}$ & $\begin{array}{l}0.68 \pm \\
0.07_{b, c, d, f}\end{array}$ & $\begin{array}{l}49.07 \pm \\
4.53^{\mathrm{a}, \mathrm{b}, \mathrm{c}}\end{array}$ & $\begin{array}{l}0.60 \pm \\
0.05_{b, c}\end{array}$ & $\begin{array}{l}0.09_{ \pm} \\
0.01^{d}\end{array}$ & $\begin{array}{l}12.85 \pm \\
1.32^{\mathrm{a}, \mathrm{b}}\end{array}$ \\
\hline November & $\begin{array}{l}0.99 \pm \\
0.11^{f}\end{array}$ & $\begin{array}{l}2.21 \pm \\
0.19^{d}\end{array}$ & $\begin{array}{l}0.82 \pm \\
0.09_{a, e, f}\end{array}$ & $\begin{array}{l}60.77 \pm \\
1.46^{\mathrm{a}}\end{array}$ & $\begin{array}{l}0.61 \pm \\
0.06_{b, d}\end{array}$ & $\begin{array}{l}0.16 \pm \\
0.02^{b, c}\end{array}$ & $\begin{array}{l}15.09_{ \pm} \\
0.47^{\mathrm{a}, \mathrm{b}}\end{array}$ \\
\hline December & $\begin{array}{l}1.14 \pm \\
0.07^{\mathrm{e}, \mathrm{f}}\end{array}$ & $\begin{array}{l}3.23 \pm \\
0.20^{\mathrm{b}, \mathrm{c}, \mathrm{d}}\end{array}$ & $\begin{array}{l}1.74 \pm \\
0.38_{a, e, f}\end{array}$ & $\begin{array}{l}55.86 \pm \\
1.22^{\mathrm{a}, \mathrm{b}}\end{array}$ & $\begin{array}{l}0.64 \pm \\
0.05_{b, e}\end{array}$ & $\begin{array}{l}0.30 \pm \\
0.01^{\mathrm{a}}\end{array}$ & $\begin{array}{l}15.20 \pm \\
0.31^{\mathrm{a}, \mathrm{b}}\end{array}$ \\
\hline January & $\begin{array}{l}2.85 \pm \\
0.23^{a}\end{array}$ & $\begin{array}{l}3.99_{ \pm} \\
0.26^{\mathrm{a}, \mathrm{b}, \mathrm{c}}\end{array}$ & $\begin{array}{l}0.89_{ \pm} \\
0.10_{a, e, f}\end{array}$ & $\begin{array}{l}48.05 \pm \\
1.20^{\mathrm{a}, \mathrm{b}}\end{array}$ & $\begin{array}{l}0.19 \pm \\
0.03_{a}\end{array}$ & $\begin{array}{l}0.20 \pm \\
0.01^{\mathrm{a}}\end{array}$ & $\begin{array}{l}14.08 \pm \\
0.51^{\mathrm{a}}\end{array}$ \\
\hline February & $\begin{array}{l}2.52 \pm \\
0.19^{a, b, c}\end{array}$ & $\begin{array}{l}3.90_{ \pm}^{ \pm} \\
0.23^{\mathrm{a}, \mathrm{b}, \mathrm{c}}\end{array}$ & $\begin{array}{l}0.74 \pm \\
0.10_{a, b}\end{array}$ & $\begin{array}{l}40.58 \pm \\
1.09^{b, c}\end{array}$ & $\begin{array}{l}0.41_{ \pm} \\
0.04_{a, b}\end{array}$ & $\begin{array}{l}0.11 \pm \\
0.03^{a, b}\end{array}$ & $\begin{array}{l}18.67 \pm \\
0.37^{\mathrm{a}}\end{array}$ \\
\hline March & $\begin{array}{l}2.43 \pm \\
0.39^{\mathrm{b}, c, d}\end{array}$ & $\begin{array}{l}5.00 \pm \\
0.28^{\mathrm{a}}\end{array}$ & $\begin{array}{l}0.86 \pm \\
0.07_{a, e, f}\end{array}$ & $\begin{array}{l}44.62 \pm \\
3.19^{b, c}\end{array}$ & $\begin{array}{l}0.31 \pm \\
0.09_{a, b}\end{array}$ & $\begin{array}{l}0.09_{ \pm} \\
0.01^{d}\end{array}$ & $\begin{array}{l}11.38 \pm \\
0.75^{\mathrm{a}, \mathrm{b}}\end{array}$ \\
\hline April & $\begin{array}{l}2.61 \pm \\
0.49^{\mathrm{a}, \mathrm{b}}\end{array}$ & $\begin{array}{l}4.72 \pm \\
0.30^{\mathrm{a}}\end{array}$ & $\begin{array}{l}0.72 \pm \\
0.08_{a, c}\end{array}$ & $\begin{array}{l}46.77 \pm \\
3.62^{\mathrm{a}, \mathrm{b}, \mathrm{c}}\end{array}$ & $\begin{array}{l}0.44 \pm \\
0.09_{a, b}\end{array}$ & $\begin{array}{l}0.10 \pm \\
0.01^{d}\end{array}$ & $\begin{array}{l}11.43 \pm \\
0.90^{\mathrm{a}, \mathrm{b}}\end{array}$ \\
\hline Average & 1.81 & 3.40 & $0.99^{d}$ & 46.71 & 0.50 & 0.14 & 13.87 \\
\hline $\begin{array}{l}\text { TEC } \\
\text { PEC }\end{array}$ & $\begin{array}{l}0.99 \\
5.0\end{array}$ & $\begin{array}{l}32 \\
150\end{array}$ & $\begin{array}{l}43 \\
110\end{array}$ & $\begin{array}{l}\text { BDL } \\
\text { BDL }\end{array}$ & $\begin{array}{l}23 \\
49\end{array}$ & $\begin{array}{l}36 \\
130\end{array}$ & $\begin{array}{l}120 \\
460\end{array}$ \\
\hline$C_{f}$ & 9.05 & 0.11 & 0.02 & $\mathrm{BDL}$ & 0.02 & 0.007 & 0.12 \\
\hline
\end{tabular}

Note; Mean values with the same superscript along the columns were not significantly different $(p>0.05) ; T E C=$ Threshold Effect Concentration; $\mathrm{PEC}=$ Probable Effect Concentration; $\mathrm{BDL}=$ Below Detection Level; $\mathrm{C}_{\mathrm{f}}$ : Contamination Factor 
Table 3 revealed that there is a significant difference between months in all the metals under consideration. Analysis of variance showed that some sediment parameters such as; $\mathrm{pH}$, iron and zinc existed a significant variation with years $(p<0.05)$, and significant seasonal variation $(\mathrm{p}<0.05)$ with $\mathrm{pH}$, electrical conductivity, organic carbon, percentage nitrogen and potassium. Chromium showed a highly significant variation with seasons and years $(p<0.01)$, while potassium revealed a highly significant variation with years $(p<0.01)$. A significant monthly variation existed with $\mathrm{pH}$, electrical conductivity and potassium $(p<0.05)$, while a highly significant monthly variation existed with chromium $(p<0.01)$.

\section{CONCLUSION}

The sediment concentrations of metals under consideration (chromium, copper, nickel, lead and zinc) in all sampling months were found to be lower than the proposed TECs, indicating that there are no harmful effects from these metals also the $C_{f}$ values were less than one $\left(C_{f}<1\right)$ and therefore are said to be low contaminated when compared with Hakanson's classification for the contamination factor and level of contamination. On the other hand, the concentration of cadmium exceeded TEC but

\section{REFERENCES}

Abata, E.O., Aiyesanmi, A.F., Adebayo, A.O. and Ajayi, 0.O. (2013). Assessment of Heavy Metal Contamination and Sediment Quality in the Urban River: A Case of Ala River in Southwestern Nigeria. IOSR Journal of Applied Chemistry, 4(3): 56-63.

Adakole, J.A., Mbah, C.E. and Dalla,M.A. (2003). A paper presented at $29^{\text {th }}$ International Conference on Millennium Development Goals, Abuja, Nigeria.

Ansari, A.A., Trivedi, S., Saggu, S. and Rehman, H. (2014). Mudskipper: A Biological Indicator for Environmental Monitoring and Assessment of Coastal Waters. Journal of Entomology and Zoology Studies, 2(6):22-33.

APHA, (2005). Standard Methods for the Examination of Water and Wastewater. American Public Health Association, American Water Works Association, Water Environment Federation, Denver, USA. Dubuque, lowa. 1287.

Bako, S.P., Ezealor, A.U. and Tanimu, Y. (2014). Heavy Metal Deposition in Soils and Plants Impacted by Anthropogenic Modification of Two less than PEC and $C_{f}$ value was greater than six $\left(C_{f}>6\right)$ in all sampling months, this indicated that the reservoir sediment is said to be slightly contaminated and therefore in a potential risk.

\section{Recommendations}

i. Responsible and sustainable agriculture practices should be carried out within the catchment area, while restricting cultivation on steep slopes to reduces the fertilization of reservoir through surface runoff.

ii. The sediment sources should be mitigated by monitoring of the reservoir inputs.

iii. Gusau populace should engage in consuming foods containing higher amounts calcium, iron, zinc and proteins, as they reduce the risk of cadmium harm which includes damage to the kidney, lungs and bones.

\section{Acknowledgements}

This is to acknowledge the technical support of Mr. Sylvanus O., Mrs. Nafisa B., Mal. Magaji A. of Hydrobiology Laboratory, Dr. Tanimu Y., Dr. I.M.K. Gadzama and Mal. A.A. Bala of Biology Department, ABU Zaria, Mal. Uba M. of Soil Science BUK and TETFund for the support.

Sites in the Sudan Savanna of Northwestern Nigeria. In: Sariano, M.A.H. (Ed) Environmental Risk Assessment of Soil Contamination. InTech, Croatia. doi: 10.5772/57299.

Balarabe M.L. (1989). Limnology and Zooplankton of Makwaye (Ahmadu Bello University Farm) Lake, Samaru, Zaria - Nigeria (Master's Dissertation, Ahmadu Bello University, Zaria Nigeria). Retrieved from http: / / hdl. handle.net/123456789/972.

Cevik, F., Goksu, M.Z.L., Derici, O.B. and Findik, O. (2009). An assessment of Metal Pollution in Surface Sediments of Seyhan Dam by Using Enrichment Factor, Geoaccumulation Index and Statistical Analyses. Environmental Monitoring and Assessment, 152: 309317.

Cheung, K.C., Poon, B.H.T., Lan, C.Y. and Wong, M.H. (2003). Assessment of metal and nutrient concentrations in river water and sediment collected from the cities in the Pearl River Delta, South China. Chemosphere, 52: 1431 1440. 
Devesa-Rey, R., Diaz-Fierros, F. and Barral, M.T. (2010). Trace Metals in River Bed Sediments: An Assessment of their Partitioning and Bioavailability by Using Multivariate Exploratory Analysis. Journal of Environmental Management. 91: 2471-2477.

Fifi, U., Winiarski, T. and Emmanuel, E. (2013). Assessing the Mobility of Lead, Copper and Cadmium in a Calcareous Soil of Port-au-Prince, Haiti. International Journal of Environmental Research and Public Health.10: 5830-5843.

Guan, Y., Shao, C.F. and Ju, M.T. (2014). Heavy Metal Contamination Assessment and Partition for Industrial and Mining Gathering Areas. International Journal of Environmental Research and Public Health.11: 7286-7303.

Hakanson, L., (1980). An Ecological Risk Indexes for Aquatic Pollution Control; a Sedimentological Approaches. Water Research, 14: 975-1001.

Hassan, F.M., Salman, J.M. and Abdulameer, M. (2014). Seasonal Variation of Environmental Properties and Phytoplankton Community in AlHussainya River, Holly Karbala-Iraq. Mesopotamia Environmental Journal, 1:56-82.

Long, E.R., Field, L.J., and Macdonald, D.D. (1998). Predicting toxicity in marine sediments with numerical sediment quality guidelines. Environmental Toxicology and Chemistry. 17:714-727.

MacDonald, D.D., Ingersoll, C.G. and Berger, T.A. (2000). Development and Evaluation of Consensus-Based Sediment Quality Guidelines for Freshwater Ecosystems. Arch. Environmental Contamination and Toxicology. 39:20-31.

Mamman, A.B., Oyebanji, J.O. and Peters, S.W. (2000). Nigeria. A People United a Future Assured. Survey of States, millennium edition, 2: 547-550.
Martin, J.M. and Meybeck, M. (1979). Elemental mass balance of materials carried by major world rivers, Mar Chem, 7: 173206.

Nasr, S.M., Okbah, M.A. and Kasem, S.M. (2006). Environmental Assessment of Heavy Metal Pollution in Bottom Sediment of Aden Port, Yemen. International Journal of Ocean oceanography, 1(1): 99-109.

NPC, (2006). National Population Commission Census, Gusau Local Government. Wikipedia, the free encyclopedia.Retrieved on 10 August, 2017, from http: / /en.wikipedia.org/wiki/Gusau.

Sabo A., Gani A.M. and Ibrahim A.Q. (2013). Pollution Status of Heavy Metals in Water and Bottom Sediment of River Delimi in Jos, Nigeria. American J. of Env. Prot. 1(3): 47-53.

Saha, P.K. and Hossain, M.D. (2011). Assessment of Heavy Metal Contamination and Sediment Quality in the Buriganga River, Banbladesh.

Udo, E.J., Ibia, T.O., Ogunwale, J.A., Ano, A.O. and Esu, I.E. (2009). Manual of Soil, Plant and Water Analyses. Sibon Books Limited.

Van Dover, C.L. (2014). Impacts of Anthropogenic Disturbances at DeepSea Hydrothermal Vent Ecosystems: A Review. Marine Environmental Research, 102:59-72.

Yang, Z.F., Wang, Y., Shen, Z.Y., Niu, J.F. and Tang, Z.W. (2009). Distribution and Speciation of Heavy Metals in Sediments from the Mainstream, Tributaries, and Lakes of Yangtze River Catchment of Wuhan, China. Journal of Hazard Materials.166: 1186-1194.

Zhang, W.G., Feng, H., Chang, J.N., Qu, J.G., Xie, H.X. and Yu, L.Z. (2009). Heavy Metal Contamination in Surface Sediments of Yangtze River Intertidal Zone: An Assessment from Different Indexes. Environmental Pollution. 157: 1533-1543. 